\title{
The duty to prevent environmental damage in the environmental liability directive; a catalyst for halting the deterioration of water and wildlife
}

\author{
Valerie Fogleman ${ }^{1,2}$ \\ Published online: 18 November 2019 \\ (C) The Author(s) 2019

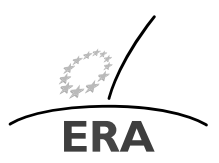 \\ EUROPÄISCHE RECHTSAKADEMIE \\ ACADEMY OF EUROPEAN LAW \\ ACADEMIE DE DROIT EUROPEEN \\ ACCADEMIA DI DIRITTO EUROPEO \\ TRIER - TREVES - TREVIRI
}

\begin{abstract}
Many articles have commented on the duty to remediate environmental damage imposed by the Environmental Liability Directive (ELD). Few-if anyarticles, however, have commented on the duty to prevent environmental damage imposed by it. This article begins to fill that gap by commenting on the duty to prevent damage to species and habitats protected by the Birds and Habitats Directives and damage to surface water under the Water Framework Directive.

The article illustrates the duty to prevent environmental damage by its application to two cases; one concerning a direct application of the duty; the other concerning an indirect application. The article concludes that the duty to prevent environmental damage under the ELD is a powerful catalyst that can trigger protective measures under the Birds, Habitats and Water Framework Directives.
\end{abstract}

Keywords Environmental Liability Directive $\cdot$ Preventive principle $\cdot$ Water damage $\cdot$ Biodiversity damage

\section{Introduction}

The Environmental Liability Directive (ELD) established 'a framework of environmental liability based on the "polluter-pays" principle to prevent and remedy environmental damage'. ${ }^{1}$ Its scope differs significantly from most national environmental

\footnotetext{
${ }^{1}$ ELD [15].

V. Fogleman

foglemanvm@cardiff.ac.uk; valerie.fogleman@stevens-bolton.com

1 Professor of Law, Cardiff University School of Law and Politics, Cardiff, UK

2 Consultant, Stevens \& Bolton LLP, Guildford, UK
} 
liability systems. National systems tend to focus-sometimes solely focus - on remediating environmental damage that has already occurred rather than preventing and remediating new damage. They also tend to focus on pollution ${ }^{2}$ rather than other types of environmental damage. Systems to remediate historic land pollution illustrate this dual focus. ${ }^{3}$

Liability under the ELD is much broader in scope. In particular, it requires an operator to carry out necessary preventive measures if there is an imminent threat of environmental damage from the operator's activities. ${ }^{4}$ If the operator fails to carry them out, the relevant competent authority has a duty to require the operator to do so $^{5}$ as well as the power to carry them out itself. ${ }^{6}$ Further, the ELD does not merely impose liability on an operator to prevent and remediate damage caused by pollutants. It also applies to other types of environmental damage such as damage to a protected species or natural habitat from the abstraction of water as well as damage to a river's ecological status caused by fluctuations in the water level from the operation of a hydroelectric power plant.

Whereas the ELD plainly requires an operator to prevent an imminent threat of environmental damage from its unauthorised activities, ${ }^{7}$ the extent of its application to authorised activities is less clear. If the Member State has adopted the so-called permit defence, the operator is not liable for remediating environmental damage caused by the authorised activities provided it is not negligent. ${ }^{8}$ The defence does not however apply to preventive measures. Must an operator, therefore, decline to carry out authorised activities if the operator knows that they may or will cause environmental damage?

This article argues that the ELD requires an operator to decline to carry out authorised activities that the operator knows will cause an imminent threat of, or actual, environmental damage or to modify those activities so that they do not cause environmental damage. If the operator nevertheless carries out such activities, the ELD can trigger a requirement on the competent authority not only to issue a prevention notice but also to vary or revoke the relevant authorisation under the Birds ${ }^{9}$ and Habitats ${ }^{10}$ Directives or the Water Framework Directive (WFD). ${ }^{11}$

To illustrate this argument, the article examines two applications of the duty under the ELD to prevent an imminent threat of environmental damage authorised by a permit; one direct and one indirect. The first—direct—application involves water abstraction and impoundment licences in England, The competent authority served a prevention notice under the ELD on the operator to reduce the amount of water

\footnotetext{
${ }^{2}$ This article refers to 'pollution' and 'contamination' as 'pollution'.

${ }^{3}$ See generally Fogleman [21], pp. 42-61.

${ }^{4}$ ELD [15], art. 5(1).

${ }^{5}$ Ibid, art. 4.

${ }^{6}$ Ibid, arts. 5(3)(d), 4.

${ }^{7}$ Ibid, art. 5(1).

${ }^{8}$ Ibid, art. 8(4)(a).

${ }^{9}$ Birds Directive [16].

${ }^{10}$ Habitats Directive [12].

${ }^{11}$ WFD [14].
} 
abstracted by it in order to prevent further damage to a population of freshwater pearl mussels (Margaritifera margaritifera; mussels), a protected species under the Habitats Directive. ${ }^{12}$ The second-indirect-application involves an authorisation for a hydroelectric power plant in Austria that allowed the operator to cause 'water damage' as defined by the ELD. The CJEU concluded that the authorisation, which was granted before the ELD was adopted, did not bar application of the ELD. ${ }^{13}$

\section{Environmental Liability Directive}

The ELD imposes strict liability on an operator that carries out activities subject to legislation listed in annex III of the ELD to prevent or remediate an imminent threat of, or actual, environmental damage caused by those activities. ${ }^{14}$ Among other things, annex III lists ' $[\mathrm{w}]$ ater abstraction and impoundment of water subject to prior authorisation [pursuant to the WFD]' 15 The ELD thus imposes strict liability on an operator to prevent or remediate environmental damage caused by its lawful abstraction or impoundment of water.

An annex III operator is not only strictly liable under the ELD for preventing and remediating water damage under the WFD ${ }^{16}$ it is also liable for preventing and remediating damage to land ${ }^{17}$ as well as damage to species and natural habitats protected by the Birds and Habitats Directives, ${ }^{18}$ with an option to Member States to impose liability for damage pursuant to national nature conservation legislation equivalent to these Directives (collectively biodiversity damage). ${ }^{19}$ Whereas damage to land is necessarily caused by pollution because the ELD refers only to 'contamination' in respect of land damage, ${ }^{20}$ damage to water and biodiversity may also be caused by other types of environmental damage.

An operator's duty to remediate water and biodiversity damage arises if its activities reach or exceed specified thresholds. The threshold for water damage is 'any damage that significantly adversely affects ... the ecological, chemical and/or quantitative status and/or ecological potential, as defined in [the WFD] of the waters concerned, with the exception of adverse effects where Article 4(7) of [the WFD] applies'. ${ }^{21}$ Article 4(7) sets out derogations (exceptions) from the WFD when, among other things, a new modification such as a dam results in the failure of a river or

\footnotetext{
${ }^{12}$ Habitats Directive [12], annex II(a), Invertebrates, Molluscs.

${ }^{13}$ Gert Folk [6].

${ }^{14}$ ELD [15], art. 3(1)(a); see ibid, arts. 5(1), 6(1), 8(1).

${ }^{15}$ Ibid, annex III, item 6.

${ }^{16}$ Ibid, art. 2(1)(b).

${ }^{17}$ Ibid, art. 2(1)(c).

${ }^{18}$ Ibid, art. 2(1)(a).

${ }^{19}$ Ibid

${ }^{20}$ See ibid, art. 2(1)(c) (defining 'land damage' as 'any land contamination that creates a significant risk of human health being adversely affected as a result of the direct or indirect introduction, in, on or under land, of substances, preparations, organisms or micro-organisms').

${ }^{21}$ Ibid, art. 2(1)(b).
} 
other surface water body ${ }^{22}$ to prevent deterioration in its status under the WFD. The derogation is conditional on the operator of the new modification meeting specified criteria set out in the WFD. ${ }^{23}$ The threshold for water damage under the ELD, however, lacks clarity. ${ }^{24}$

The threshold for biodiversity damage is 'any damage that has significant adverse effects on reaching or maintaining the favourable conservation status of [protected] habitats or species ...' ${ }^{25}$ This links the threshold with measures taken pursuant to the Habitats Directive 'to maintain or restore, at favourable conservation status, natural habitats and species of wild fauna and flora of Community interest' ${ }^{26}$ The ELD states that the 'conservation status' of a species is the influences that act on the species that may affect its 'long-term distribution and abundance of its populations within, as the case may be, the European territory of the Member States to which the Treaty applies or the territory of a Member State or the natural range of that species'. ${ }^{27}$ A species has a 'favourable conservation status' if it is able to maintain itself in the long term. ${ }^{28}$ The threshold for biodiversity damage is unclear as to whether a significant effect on reaching or maintaining the favoured conservation status of a species may occur at EU level, Member State level, or natural range level, or whether an effect cannot be significant unless it occurs at all three levels. ${ }^{29}$

If an operator's activities reach or exceed the thresholds for water or biodiversity damage, the operator is liable for:

- remediating the damage to its baseline condition (primary remediation);

- any additional remediation to compensate if the primary remediation does not fully restore the water or biodiversity and/or services (complementary remediation); and

- additional measures to compensate for interim losses between the time of the damage and its full restoration (compensatory remediation). ${ }^{30}$

The thresholds for water and biodiversity damage mean that the ELD does not apply to damage that does not reach or exceed the thresholds. Member States have interpreted the thresholds, including the threshold for land damage, in different ways, ${ }^{31}$

${ }^{22}$ A 'body of surface water' is defined as 'a discrete and significant element of surface water such as a lake, a reservoir, a stream, river or canal, part of a stream, river or canal, a transitional water or a stretch of coastal water'. WFD [14], art. 2(10).

${ }^{23}$ WFD [14], art. 4(7).

${ }^{24}$ See Josefsson [25], p. 161.

${ }^{25}$ ELD [15], art 2(1)(a). The significance of the effects is 'assessed with reference to the baseline condition, taking account of the criteria set out in Annex I'. Ibid. The 'baseline condition' is defined as 'the condition at the time of the damage of the natural resources and services that would have existed had the environmental damage not occurred ...' '. Ibid, art. 2(14). Annex I sets out criteria such as the number, density and role of individuals in a species and the rarity of a species or habitat. Ibid, art. 2(1)(a) and annex I.

${ }^{26}$ Habitats Directive [12], art. 2(2).

${ }^{27}$ ELD [15], art. 2(4)(b).

${ }^{28}$ Ibid, art. 2(4)(b).

${ }^{29}$ See Fogleman, Threshold [22], 202-03.

${ }^{30}$ ELD [15], annex II.

${ }^{31}$ Commission Report [30], s. 3.2. 
generally perceiving them to be high or even 'excessive'. ${ }^{32}$ This has resulted, among other things, in reports of only a few, or sometimes no, ELD incidents in some Member States. ${ }^{33}$

The ELD includes an option for Member States to adopt a 'permit defence'. According to this defence, an operator is not required to bear the cost of remedial actions if it demonstrates that it was not at fault or negligent and the environmental damage was caused by an emission or event 'expressly authorised by, and fully in accordance with the conditions of, an authorisation conferred by or given under applicable national laws and regulations' that implement measures pursuant to legislation in annex III. ${ }^{34}$ Seventeen Member States have adopted the defence. ${ }^{35}$

The duty to prevent environmental damage under the ELD is significantly different from the duty to remediate it. An operator has a duty to carry out preventive measures if its activities cause an 'imminent threat' of environmental damage, defined as 'a sufficient likelihood that environmental damage will occur in the near future' ${ }^{36}$ The 'preventive measures' that the operator must carry out in such a case are defined as 'any measures taken in response to an event, act or omission that has created an imminent threat of environmental damage, with a view to preventing or minimising that damage' 37

The thresholds for water or biodiversity damage do not apply to measures to prevent environmental damage in that there is no need for the damage to reach or exceed them before the ELD applies. It is sufficient that there is an imminent threat of such damage. Further, because the permit defence does not apply to preventive measures, an operator whose authorised activities cause an imminent threat of environmental damage cannot plead compliance with its permit as a defence to liability.

\section{Direct application of the duty to prevent environmental damage}

The direct application of the duty to prevent environmental damage is illustrated by a case that involves water abstraction and impoundment licences. United Utilities, an English water company, had a licence to abstract water for public supply from the River Ehen, which flows out of Ennerdale Water in Cumbria, as well as an impoundment licence to maintain and operate a weir at the outlet to the river. ${ }^{38}$ The weir raised the water level in the lake by up to one metre. ${ }^{39}$ The licences had existed for many years. Indeed, water had been abstracted from Ennerdale Water since

\footnotetext{
${ }^{32}$ REFIT Evaluation [7], p. 35.

${ }^{33}$ Ibid, p. 24.

${ }^{34}$ ELD, art. 8(4)(a).

${ }^{35}$ See ELD Effectiveness Study [2], pp. 134-38. Three of these Member States have not applied the defence to genetically modified organisms. Ibid.

${ }^{36}$ ELD [15], art. 2(9).

${ }^{37}$ Ibid, art. 2(10).

${ }^{38}$ The abstraction licence is licence No 2774003 008. The impoundment licence is No 2774003012. Abstractions [34].

${ }^{39}$ O'Leary [27], p. 12.
} 
the late $1800 \mathrm{~s}^{40}$ The abstraction, however, harmed a population of 550,000 mussels, the largest viable population in England ${ }^{41}$ and the only population not in danger of extinction without significant intervention. ${ }^{42}$

In 1997, a 13.5 kilometre stretch of the River Ehen from its outlet at the lake was designated as a site of special scientific interest (SSSI) under the Wildlife and Countryside Act $1981 .{ }^{43}$ A slightly larger area was subsequently designated as a special area of conservation (SAC) under the Habitats Directive. ${ }^{44}$

England has applied the ELD to SSSIs. Whilst all SACs are SSSIs, the threshold for damage to an SSSI differs from that for biodiversity damage under the ELD. The threshold for damage to an SSSI is damage that has 'an adverse effect on the integrity of the [SSSI] (that is, the coherence of its ecological structure and function, across its whole area, that enables it to sustain the habitat, complex of habitats or the levels of populations of the species affected)'. ${ }^{45}$ The threshold, therefore, applies to a single site thus avoiding the lack of clarity in the ELD threshold for damage to a species or natural habitat protected under the Habitats Directive.

The reason for the site's designation as an SSSI was the presence of mussels and Atlantic salmon (Salmo salar) (salmon). ${ }^{46}$ Mussels depend on the presence of salmon for their survival. After the male mussels release sperm into the water and the females inhale it and fertilise the eggs, the females release the resulting larvae (glochidia) into the river. The glochidia are then inhaled by salmon and held on the salmon's gill filament until they drop off the following spring. The mussels then burrow into substrata between boulders and cobbles in the river, where they can grow to 155 millimetres in length and live for over 100 years. ${ }^{47}$ As indicated above, abstraction of water from the SAC/SSSI adversely affected the mussels. In addition the presence of the weir adversely affected the number of salmon reaching the SAC/SSSI ${ }^{48}$

In 2011, the Environment Agency, the competent authority for damage to protected species and natural habitats and SSSIs in respect of water in England, ${ }^{49}$ carried out a review of abstraction licences in Cumbria under the Habitats Directive to ensure that areas such as the River Ehen SAC were protected. ${ }^{50}$ The Agency discovered that the mussels in the SAC were subject to severe stress and mortality across all age groups caused by low flows and exacerbated by rapid rises and falls in the flow of the river. The Agency concluded that minimum flows in the river must be maintained

\footnotetext{
${ }^{40}$ Ibid, p. 18.

${ }^{41}$ Ibid, p. 6. The second and third largest populations, in the Rivers Tyne and Rede, have less than 20,000 adult mussels in each. See Proposed package [29], p. 5.

${ }^{42}$ Cascade Consulting [3], p. 23.

${ }^{43}$ O'Leary [27], p. 5; see Wildlife and Countryside Act 1981 [41], s. 28.

${ }^{44}$ O'Leary [27], p. 5; see Habitats Directive [12], art. 1(1).

${ }^{45}$ EDR [19], sched. 1, para. 4(2). Scotland has not applied the ELD to nationally protected sites.

${ }^{46}$ O'Leary [27], p. 5; Natura 2000—Standard Data Form [26].

${ }^{47}$ O'Leary [27], p. 3.

${ }^{48}$ Ibid, p. 8.

${ }^{49}$ EDR [19], sched. 2A.

${ }^{50}$ See Abstraction licence [1].
} 
to prevent further damage to the mussels. ${ }^{51}$ At that time, United Utilities, which had gradually reduced the amount of abstracted water, ${ }^{52}$ was authorised under its abstraction licence and operating permit to abstract water provided there was a minimum compensation flow into the River Ehen of 31.8 million litres per day. ${ }^{53}$

On 19 December 2012, the Environment Agency served a prevention notice on United Utilities under the Environmental Damage Regulations (EDR), ${ }^{54}$ which implement the ELD in England. ${ }^{55}$ The Agency served the notice on the basis that damage caused by the water abstraction was adversely affecting the natural habitat of the mussels in the SSSI. ${ }^{56}$ The notice required United Utilities to increase the minimum compensation flow in order to enable the mussels to recover by reducing the stress caused by periods of low flows in the river. ${ }^{57}$ The Agency had considered serving a remediation notice on United Utilities to remedy the damage to the mussels in the SSSI but did not do so because United Utilities had a permit defence under the EDR due to its abstraction licence. ${ }^{58}$

The Agency also reviewed United Utilities' abstraction and impoundment licences to consider whether to vary them. The substantive conditions of the prevention notice would then be continued by new conditions in the varied licences and a separate legal agreement with United Utilities under the Water Resources Act 1991, which authorised the licences. 59

On 21 May 2013, the Agency revised the prevention notice to impose further restrictions on abstraction and impoundment. ${ }^{60}$ On 28 February 2014, the Agency again revised the prevention notice after concluding that continued abstraction of water pursuant to the licence would likely have a significant effect on the River Ehen SAC/SSSI. ${ }^{61}$ The Agency also concluded that the only course of action to remove the adverse effect on the integrity of the SAC/SSSI was to revoke the licence and to remove the weir. ${ }^{62}$

In order to continue to provide water to the public in the absence of the licences, United Utilities began constructing a pipeline from Thirlmere reservoir, also in Cumbria. ${ }^{63}$ Until the pipeline is completed, it is continuing to abstract water from the River Ehen SAC under a derogation pursuant to Sect. 6(4) of the Habitats Directive as a case of imperative reasons of overriding public interest because no alternative water

\footnotetext{
${ }^{51}$ Incidents Report [13].

${ }^{52}$ See Hall [23].

${ }^{53}$ Planning Inspectorate Report [28], p. 20, para. 4.12.

${ }^{54}$ Incidents Report [13]; see EDR [19], reg. 14(2).

${ }^{55}$ Reg. 14(2), EDR 2009 [20], now EDR [19]. Different, but similar, regulations apply to Scotland, Wales and Northern Ireland.

${ }^{56}$ Incidents Report [13].

${ }^{57}$ Planning Inspectorate Report [28], p. 20, para. 4.12; Proposed package [29], pp. 36-37.

${ }^{58}$ Incidents Report [13]; see EDR, reg. 19(3)(d) and sched. 4, para 1(d)

${ }^{59}$ Incidents Report [13]; Water Resources Act 1991 [39], ch. II, Abstraction and impounding.

${ }^{60}$ Water Resources Review [37], pp. 30-31; Documents List [35]; see O'Leary [27], p. 12.

${ }^{61}$ Proposed package [29], p. 1.

${ }^{62}$ See Revised Draft Water Resources Management Plan [36], pp. 4-5.

${ }^{63}$ See ibid, p. 3.
} 
supply solutions exist. ${ }^{64}$ The abstraction is expected to cease by 31 March $2022 .{ }^{65}$ Further, as required by article 6(4) of the Habitats Directive, United Utilities, the Environment Agency, and Natural England (the relevant nature conservation authority) agreed to compensatory measures to restore the natural habitat for the mussels and salmon in the SAC. ${ }^{66}$

The Agency has the power to vary or revoke abstraction and impoundment licences under the Water Resources Act 1991. ${ }^{67}$ Crucially, the WFD directs Member States to have a system of controls and prior authorisation of abstractions and impoundments. ${ }^{68}$ It provides, among other things, that if monitoring and other data indicate that environmental objectives under the WFD are unlikely to be achieved for a water body, the Member State 'shall ensure that ... relevant permits and authorisations are examined and reviewed as appropriate' ${ }^{69}$

The relationship between the ELD, the Habitats Directive, and the WFD is clearly evident in the above case. Whereas the ELD imposes liability for preventing and remediating environmental damage, the Habitats Directive directs Member States to conserve species and natural habitats protected by it and the Birds Directive by establishing conservation measures for SACs to avoid the deterioration of species and natural habitats at them. ${ }^{70}$ These measures may include restrictions or even prohibitions on former activities carried out at them. ${ }^{71}$ In addition, the WFD requires the variation and revocation of abstraction and impoundment licences that deteriorate surface waters.

\section{Indirect application of the duty to prevent environmental damage}

The indirect application of the duty to prevent environmental damage involves the operation of a hydroelectric power plant. Wasserkraftanlagen Mürzzuschlag GmbH (WMG) began operating a hydroelectric power plant on the River Mürz in Austria in 2002, after having been granted an authorisation to do so by the Governor of Styria on 20 August 1998. The authorisation was granted in the knowledge that normal operation of the power plant included stopping the turbine several times a year. Stopping the turbine caused water impounded in the reservoir at the plant to cease to flow through the turbine, resulting in significant short-term fluctuations in water dis-

\footnotetext{
${ }^{64}$ Proposed package [29], p. 5; see Habitats and Species Regulations 2010 [9] (now Habitats and Species Regulations 2017 [10], regs 62(5) and 64(2). Regulation 62(5) of the 2010 regulations is now Regulation 64(5) of the 2017 regulations; regulation 64(2) is now regulation 66(2).

${ }^{65}$ See Douglas [18] p. 2; see also West Cumbria Rivers Trust [40]; Cascade Consulting [3], p. 25.

${ }^{66}$ See Water Resources Review [37], p. 24 fn **.

${ }^{67}$ Water Resources Act 1991 [39], s. 52(1).

${ }^{68}$ WFD [14], art. 11(3)(e). There is an exception for abstractions and impoundments that have no significant effect on the status of water. Ibid.

${ }^{69}$ Ibid, art. 11(5).

${ }^{70}$ Habitats Directive [12], art. 6(2). The protections also apply to special protection areas under the Birds Directive.

${ }^{71}$ See Verschuuren [38], p. 255.
} 
charged by the plant. ${ }^{72}$ The fluctuations caused the death of fish that were stranded as the water receded from formerly submerged areas of the riverbed away from the main current of the river. ${ }^{73}$ A by-pass channel, which would have allowed fish to re-join the river during the fluctuations in water level, was not constructed. ${ }^{74}$

When the authorisation was granted, Austria was not under a duty to include conditions in a permit to avoid the deterioration of a surface water body. That duty existed only after the WFD entered into force on 22 December $2000,{ }^{75}$ with a deadline of 22 December 2003 for its transposition into Member State law. ${ }^{76}$

On 29 September 2009, Mr Folk, who owned fishing rights for both banks of a 12 kilometre stretch of the river downstream from the power plant, lodged a complaint with the Mürzzuschlag District Administration, the relevant competent authority under the ELD. Mr Folk alleged that the fluctuations had caused water damage under the ELD because they had a significant adverse effect on the ecological status of the river, ${ }^{77}$ which includes the '[c]omposition, abundance and age structure of fish fauna', ${ }^{78}$ in that they disrupted the natural reproduction of fish. ${ }^{79}$ The competent authority rejected Mr Folk's complaint. ${ }^{80}$

On 15 May 2012, the Independent Administrative Chamber for the Land of Styria rejected Mr Folk's application for review on the basis that the power plant had been authorised in compliance with the Austrian Water Act of 1959 (Wasserrechtsgesetz; WRG). The Chamber ruled that paragraph 4(1) of the Federal Environmental Liability Act (BundesUmwelthaftungsgesetz; B-UHG), which had transposed the ELD into Austrian law, applied. Paragraph 4(1) did not include an exception from water damage under the ELD for article 4(7) of the WFD but excluded instead 'an authorisation pursuant to the [WRG]' ${ }^{81}$ Unlike article 4(7), paragraph 4(1) of the B-UHG was not subject to any conditions. Thus, if a hydroelectric power plant or other facility was authorised by the WRG, paragraph 4(1) of the B-UHG provided that any damage caused by the power plant was not 'water damage' under the ELD. The Chamber ruled that the authorised power plant had not caused water damage under the ELD despite damage caused by it to the ecological status of the river, including damage to the natural reproduction of fish. ${ }^{82}$

\footnotetext{
${ }^{72}$ Gert Folk [6], para. 15.

73 Ibid.

${ }^{74}$ Ibid.

${ }^{75}$ WFD [14], art. 25.

${ }^{76}$ Ibid, art. 24(1).

${ }^{77}$ Bobek [5], para. 12; see ELD [15], art. 2(1)(b); see also ELD [15], art. 12.

${ }^{78}$ WFD [14], annex V, Surface Water Status 1.1.1.

${ }^{79}$ Bobek [5], para. 12.

${ }^{80}$ Gert Folk [6], para. 16.

${ }^{81}$ Paragraph 4(1) of the B-UHG defined 'environmental damage' in pertinent part as 'any significant damage to water, that is to say, any damage that has a significant adverse effect on the ecological, chemical or quantitative status or ecological potential, as defined in the 1959 Wasserrechtsgesetz [1959 Law on matters relating to water, "WRG"], of the waters concerned ... and that is not covered by an authorisation granted pursuant to the [WRG]'. Gert Folk [6], para. 10 (quoting B-UHG, para. 4(1)).
}

${ }^{82}$ Gert Folk [6], para. 17. 
Mr Folk appealed the Chamber's decision to the Administrative Court on the basis that the B-UHG was not compatible with the ELD because every authorisation granted under the WRG could lead to the exclusion of liability for water damage. ${ }^{83}$ The Administrative Court stayed the proceedings and referred four questions to the CJEU, one of which was whether the ELD precludes national law that provides that damage that has a significant adverse effect on the ecological, chemical or quantitative status or ecological potential of water is not 'water damage' under the ELD if the damage is authorised. ${ }^{84}$

In determining whether the ELD precludes paragraph 4(1) of the B-UHG, the CJEU reviewed article 4(7) of the WFD. Article 4(7) provides, among other things, that a Member State is not in breach of the WFD if '[the] failure ... to prevent deterioration in the status of a body of surface water ... is the result of new modifications to the physical characteristics of a surface water body ... ${ }^{85}$ In order to fall within this derogation, the Member State must satisfy four conditions including taking all practicable steps to mitigate the adverse impact on the status of the body of water, and showing that the beneficial objectives served by the modifications cannot be achieved by a significantly better environmental option. ${ }^{86}$ In other words, the WFD provides an exception to the requirement for a Member State to prevent deterioration of the status of part or all of a surface water body if the reason for that failure is a new modification to the physical characteristics of the water body provided that the conditions specified in article 4(7) are satisfied.

In his opinion on the case, AG Bobek had commented that Austria had not adopted the permit defence in its transposition of the ELD, ${ }^{87}$ noting that the defence does not apply to actions to prevent environmental damage. ${ }^{88}$

The CJEU commented that the authorisation of the power plant had not been subject to the conditions in article 4(7) because the authorisation occurred before the WFD was adopted. ${ }^{89}$ The court stated, however, that article 4(7) 'does not solely concern projects subject to authorisation' ${ }^{90}$ Instead, it 'applies to all situations of deterioration of bodies of water, whether due to a facility or not, and provides for cases where, faced with such deterioration, Member States are nevertheless exempted from taking action'. ${ }^{91}$ Thus, Austria could not exempt liability for water damage under the ELD by activities subject to an authorisation granted before the WFD came into force. The CJEU thus concluded that the operator of the hydroelectric power plant

\footnotetext{
${ }^{83}$ Ibid, para. 18.

${ }^{84}$ Ibid, para. 19. The other three questions concerned the temporal provisions of the ELD, the necessity of a court considering the criteria in article 4(7) if those criteria had not been considered when authorisation was granted, and the access to justice provisions of the ELD. Ibid.

${ }^{85}$ WFD [14], art. 4(7).

${ }^{86}$ Ibid.

${ }^{87}$ Bobek [5], para. 50; see Commission Report [31], p. 4, s. 2.2.

${ }^{88}$ Bobek [5], para. 51.

${ }^{89}$ Gert Folk [6], para. 33.

${ }^{90}$ Ibid, para. 32.

${ }^{91}$ Ibid.
} 
was potentially liable for causing water damage under the ELD despite the plant's authorisation before the ELD was adopted. ${ }^{92}$

The question arises as to the remedy sought by Mr Folk in the case. He was not seeking, and could not seek, compensation for the loss of his past or future fishing rights in the River Mürz. The ELD does not apply to such compensation. ${ }^{93}$ Further, the focus of Mr Folk's action does not appear to be remedial measures. Even if remedial measures were carried out, the repetitive stopping of the turbine would continue to result in the deaths of fish downstream of the power plant. Instead, it appears that Mr Folk was seeking to request the court to direct the competent authority to require the operator of the power plant to prevent future water damage. Preventive measures could include construction of a by-pass channel for fish. The CJEU had noted in Commission v Austria that measures including limitation of the effect on fish migration patterns had been carried out for a hydroelectric power plant on the Schwarze Sulm, another river in Styria. ${ }^{94}$

\section{Extent of the duty to prevent environmental damage}

The duty to prevent an imminent threat of damage to water and biodiversity clearly covers the removal of say a large deteriorating barrel of toxic pollutants that has begun to leak next to a river in a protected natural habitat. Removal of the barrel is indisputably a measure to prevent an imminent threat of water damage. It is less clear, however, the extent to which the duty to prevent environmental damage applies to activities authorised by a permit if those activities are known, or are likely, to cause, environmental damage. If the activities have caused environmental damage in the past, there would seem to be 'a sufficient likelihood that environmental damage would occur in the near future' if they are carried out again. Arguably, the operator must modify the activities so that they do not cause environmental damage or, if this is not possible, decline to carry them out.

If the ELD requires authorised activities to be prevented from causing environmental damage, a corollary issue is the types of measures covered by the term 'preventive measures'. Constructing a by-pass channel for fish to prevent the deterioration of the ecological status of a surface water body would undeniably be a preventive measure. It is less clear, however, whether the variation or revocation of the permit that authorises the activities is a preventive measure; that is, whether it is a measure 'taken in response to an event, act or omission that has created an imminent threat of environmental damage ... ${ }^{95}$ If environmental damage had occurred as a result of carrying out the activities in the past, a variation or revocation would seem to be measures taken in response to an act that caused environmental damage and not an act that 'created an imminent threat of environmental damage'. ${ }^{96}$ More importantly, only a

\footnotetext{
${ }^{92}$ Ibid, paras. 33-34.

${ }^{93}$ ELD [15], recital 14.

${ }^{94}$ Commission v Austria [4], para 77.

${ }^{95} \mathrm{ELD}$ [15], art. 2(10).

${ }^{96}$ Ibid.
} 
competent authority can vary or revoke a permit; an operator cannot do so. Arguably, therefore, the variation or revocation of a permit that authorises an operator to cause an imminent threat of, or actual, environmental damage is not a 'preventive measure' under the ELD.

The issue is further complicated by the absence of a specific reference to the preventive principle in the ELD. Article 1 of the ELD provides that its purpose "is to establish a framework of environmental liability based on the "polluter-pays" principle, to prevent and remedy environmental damage'. Recital 2 states that the 'prevention and remedying of environmental damage should be implemented through the furtherance of the "polluter pays" principle, as indicated in the Treaty ...'.

The focus on only the polluter pays principle may result from the history of the ELD. For example, in 1993, the Commission published a Green Paper on Remedying Environmental Damage, not on preventing as well as remedying such damage. The Green Paper nevertheless referred to the preventive principle by stating that ' $\mathrm{t}] \mathrm{he}$ preventive principle is involved in that potential polluters would know they will be liable for the costs of remedying the damage they cause [and thus] have a strong incentive to avoid causing such damage' ${ }^{97}$

The reference only to the polluter pays principle in the ELD was not because the preventive principle did not exist when the Green Paper was published. By that time, both the preventive principle and the polluter pays principle were in the then EEC Treaty (now in the Treaty on the Functioning of the European Union), ${ }^{98}$ having been inserted into it by the Single European Act. ${ }^{99}$ Further, other EU environmental legislation such as the Industrial Emissions Directive ${ }^{100}$ and the WFD ${ }^{101}$ specifically refers to both principles.

One reason for the absence of the preventive principle may be its somewhat limited scope in the ELD. The fundamental principle of the ELD is:

that an operator whose activity has caused the environmental damage or the imminent threat of such damage is to be held financially liable, in order to induce operators to adopt measures and develop practices to minimise the risks of environmental damage so that their exposure to financial liabilities is reduced. ${ }^{102}$

If the operator's activities cause environmental damage, the variation or revocation of the permit that authorises the activity does not further this fundamental principle.

${ }^{97}$ Green Paper [8], p. 5, s. 1.0.

${ }^{98}$ TFEU [11], art. 191(2) ('Union policy on the environment shall aim at a high level of protection taking into account the diversity of situations in the various regions of the Union. It shall be based on the precautionary principle and on the principles that preventive action should be taken, that environmental damage should as a priority be rectified at source and that the polluter should pay').

${ }^{99}$ Single European Act [32], art. 130r(2).

${ }^{100}$ IED [17], recital 2 ('In order to prevent, reduce and as far as possible eliminate pollution arising from industrial activities in compliance with the "polluter pays" principle and the principle of pollution prevention, it is necessary to establish a general framework for the control of the main industrial activities ...').

${ }^{101}$ WFD [14], recital 11 ('Community policy on the environment is... to be based on the precautionary principle and on the principles that preventive action should be taken, environmental damage should, as a priority, be rectified at source and that the polluter should pay').

${ }^{102}$ ELD [15], recital 2. 


\section{Conclusion}

The extent of the application of the preventive principle in the ELD to environmental damage caused by an operator's authorised activities is unclear. Further, the variation or revocation of a permit that authorises environmental damage does not appear to be a preventive measure under the ELD.

Both the English and the Austrian cases irrefutably demonstrate, however, that the preventive principle in the ELD can act as a catalyst for action under the Habitats and Birds Directives and the WFD. As illustrated by the English case, a competent authority can serve a prevention notice and, depending on whether it adequately prevents new or further environmental damage, revise the notice to strengthen the restrictions in it. The conditions in the notice can be subsequently continued by varying or revoking the permit that authorised the damage.

The variation or revocation of abstraction licences obviously depends, among other things, on the implementation of national law that transposed the WFD. In some Member States such as the United Kingdom, difficulties have arisen as prior law concerning abstraction licences including exemptions of some major abstractions from licensing is revised in accordance with the WFD. ${ }^{103}$ Also, as indicated by the new measures to provide water for public supply following the variation of the abstraction and impoundment licences at Ennerdale Water, new - and costly - measures may take some time to be carried out even after they have been instigated. This situation is not unique to the United Kingdom. It has also arisen in other Member States such as Sweden, where reviewing water permits to reflect new environmental requirements has also proven to be complex and costly. 104

The ELD has however another, corollary, tool in halting the deterioration of water and wildlife in the EU. In the English case, it was the competent authority that instigated the actions to stop the deterioration of the protected species and its natural habitat. In the Austrian case, it was a member of the public, Mr Folk, who used the public comment powers under the ELD to request the competent authority to halt the significant adverse effect on the river downstream of the hydroelectric power plant ${ }^{105}$ When the request was declined, Mr Folk judicially reviewed the competent authority's decision under the ELD's access to justice provisions, ${ }^{106}$ leading to the resulting decision in his favour from the CJEU.

Publisher's Note Springer Nature remains neutral with regard to jurisdictional claims in published maps and institutional affiliations.

Open Access This article is distributed under the terms of the Creative Commons Attribution 4.0 International License (http://creativecommons.org/licenses/by/4.0/), which permits unrestricted use, distribution, and reproduction in any medium, provided you give appropriate credit to the original author(s) and the source, provide a link to the Creative Commons license, and indicate if changes were made.

\footnotetext{
${ }^{103}$ Howarth [24], pp. 317-18.

${ }^{104}$ Söderasp, [33], p. 274.

${ }^{105}$ ELD [15], art. 12.

${ }^{106}$ Ibid, art. 13.
} 


\section{References}

1. Abstraction licence changes drive United Utilities to drill for water in West Cumbria, Water Briefing (4.2.2011). https://www.waterbriefing.org/home/company-news/item/3824-abstraction-licencechanges-drive-united-utilities-to-drill-for-water-in-west-cumbria

2. Bio Intelligence Service, Stevens \& Bolton LLP: Study on ELD Effectiveness: Scope and Exceptions (final report prepared for the Commission-DG Environment, 19.2.2014)

3. Cascade Consulting: United Utilities plc; West Cumbria Water Supplies Project-Thirlmere Transfer, Environmental Statement, Volume 4 - Technical Appendices, Appendix 11.13-Information to Inform the Appropriate Assessment (Habitat Regulations Assessment Stage 2) (17.3.2016)

4. Case C-346/14 Commission v Austria ECLI:EU:C:2016:322

5. Case C-529/15 Gert Folk v Unabhängiger Verwaltungssenat für die Steiermark (CJEU, Opinion of AG Bobek, 10.1.2017)

6. Case C-529/15 Gert Folk v Unabhängiger Verwaltungssenat für die Steiermark, ECLI:EU:C: 2017:419

7. Commission Staff Working Document, REFIT Evaluation of the Environmental Liability Directive Accompanying the document Report from the Commission to the Council and the European Parliament under Article 18(2) of Directive 2004/35/EC on environmental liability with regard to the prevention and remedying of environmental damage. 14.4.2016, SWD(2016) 121 final

8. Communication from the Commission to the Council and Parliament and the Economic and Social Committee: Green Paper on Remedying Environmental Damage, 14.05.1993, COM(93) 47, final

9. Conservation of Habitats and Species Regulations 2010/490

10. Conservation of Habitats and Species Regulations 2017/1012

11. Consolidated Version of the Treaty on the Functioning of the European Union [2012] OJ C 326/47

12. Council Directive $92 / 43$ of 21 May 1992 on the conservation of natural habitats and of wild fauna and flora [1992] OJ L 206/7 (consolidated version)

13. Department for Environment, Food and Rural Affairs, Environmental Liability, Incidents Report 2012, Incident 1; http://data.defra.gov.uk/Environmental_Liability_Incidents_Reports/eld_2012_return.xls

14. Directive 2000/60/EC of the European Parliament and of the Council of 23 October 2000 establishing a framework for Community action in the field of water policy [2000] OJ L 327/1

15. Directive 2004/35/CE of the European Parliament and of the Council of 21 April 2004 on environmental liability with regard to the prevention and remedying of environmental damage [2004] OJ L 143/56 (consolidated version)

16. Directive 2009/147 of the European Parliament and of the Council on 30 November 2009 on the conservation of wild birds [2010] OJ L 20/7 (consolidated version)

17. Directive 2010/75/EU of the European Parliament and of the Council of 24 November 2010 on industrial emissions (integrated pollution prevention and control) [2010] OJ L 334/17

18. Douglas, M.: Ecological Appraisal-Summary Document, United Utilities Compensatory Measures Areas, Ennerdale (Report 1116/3b, 9.11.2016). https://www.westcumbriariverstrust.org/assets/ content/projects/downloads/ecological-appraisal-summary.pdf

19. Environmental Damage (Prevention and Remediation) (England) Regulations, SI 2015/810

20. Environmental Damage (Prevention and Remediation) Regulations, SI 2009/153

21. Fogleman, V.: Landowners' liability for remediating contaminated land in the EU: EU or national law? Part II: national law. Environ. Liabil. 23(2), 42 (2015)

22. Fogleman, V.: The threshold for liability for ecological damage in the EU: mixing environmental and conservation law 181. In: Born, C-H., Cliquet, A., Schoukens, H., Misonne, D., Van Hoorick, G. (eds.) The Habitats Directive in Its EU Environmental Law Context: European Nature's Best Hope? Routledge, London (2015)

23. Hall, J.: Managing water resources in West Cumbria (21.8.2015). https://environmentagency.blog. gov.uk/2015/08/21/managing-water-resources-in-west-cumbria/

24. Howarth, W.: Going with the flow: Integrated Water Resources Management, the EU Water Framework Directive and ecological flows. Leg. Stud. 38, 298 (2018)

25. Josefsson, H.: The Environmental Liability Directive, the Water Framework Directive and the definition of 'water damage'. Environ. Law Rev. 31(2), 151 (2018)

26. Natura 2000-Standard Data Form; Special Areas of Conservation under the EC Habitats Directive (includes candidate SACs, Sites of Community Importance and designated SACs), River Ehen, Site UK0030057 (25.1.2016). http://archive.jncc.gov.uk/protectedsites/sacselection/n2kforms/ uk0030057.pdf 
27. O'Leary, D.: Pearls in Peril LIFE+ GB; Action A3: Conservation Actions for the Freshwater Pearl Mussel in the River Ehen, Cumbria; September 2013-2016 (6.9.2014). http://ec.europa.eu/ environment/life/project/Projects/index.cfm?fuseaction=home.showFile\&rep=file \&fil=PIP-GB_ River-ehen-conservation.pdf

28. Planning Inspectorate: Report to the Secretary of State for Environment, Food and Rural Affairs by Stephen Roscoe, Water Resources Management Plan Regulations 2007, Examination in Public into the United Utilities Revised Draft Water Resources Management Plan November 2013 (APP/WRMP/14/3, 17.11.2014). http://www.hwa.uk.com/site/wp-content/uploads/2017/09/ Inspectors-Report-WRMP-United-Utilities-EiP-2014-.pdf

29. Proposed package of compensatory measures for adverse effects on the River Ehen SAC (28.2.2014)

30. Report from the Commission to the Council and the European Parliament under Article 18(2) of Directive 2004/35/EC on environmental liability with regard to the prevention and remedying of environmental damage. 14.04.2016, COM(2016) 204 final

31. Report from the Commission to the Council, the European Parliament, the European Economic and Social Committee and the Committee of the Regions Under Article 14(2) of Directive 2004/35/CE on the environmental liability with regard to the prevention and remedying of environmental damage, 12.10.2010, COM(2010) 581 final

32. Single European Act [1987] OJ L 169/1

33. Söderasp, J., Pettersson, M.: Before and after the Weser case: legal application of the Water Framework Directive environmental objectives in Sweden. J. Environ. Law 31(2), 265 (2019)

34. The operation of abstractions from South Egremont Boreholes and Ennerdale Water, Agreement under Section 20 of the Water Resources Act 1991 between United Utilities Water Ltd and The Environment Agency (21.7.2015)

35. United Utilities Draft Water Resources Management Plan, West Cumbria Resource Zone, Examination in Public, Documents List. http://www.hwa.uk.com/site/wp-content/uploads/2017/09/ Examination-Documents-List-15-9-2014.pdf

36. United Utilities, Revised Draft Water Resources Management Plan 2019; Technical Report-West Cumbria legacy (2018). https://www.unitedutilities.com/globalassets/z_corporate-site/about-us-pdfs/ water-resources/revised-draft-wrmp19-technical-report-west-cumbria-legacy.pdf

37. United Utilities: Water Resources Review; April 2013 to March 2014. https://www.cumbria.gov.uk/ elibrary/Content/Internet/538/755/1929/42117113021.pdf

38. Verschuuren, J.M.: Implementation of the convention on biodiversity in Europe: 10 years of experience with the Habitats Directive. J. Int. Wildl. Law Policy 5, 251 (2002)

39. Water Resources Act 1991

40. West Cumbria Rivers Trust. https://www.westcumbriariverstrust.org/projects/river-ehen/background

41. Wildlife and Countryside Act 1981, as amended 